
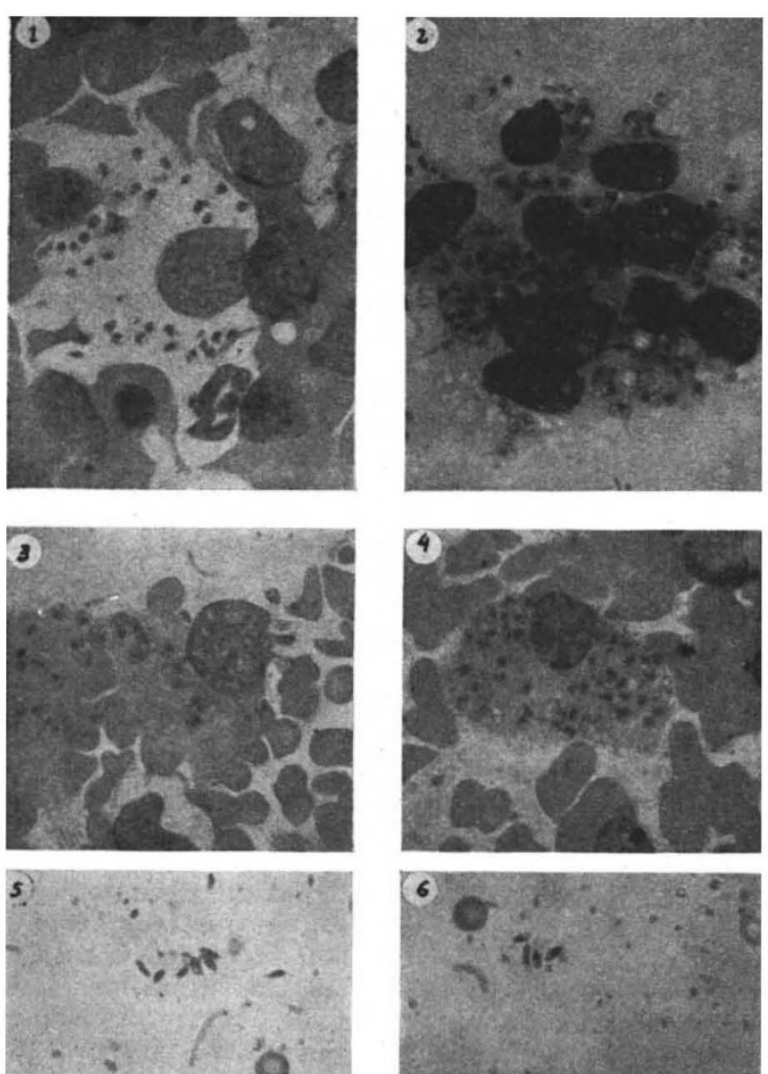

Figs. 1 and 2. Touch preparations from spleen of hamster $H 1907$ 56 days after inoculation with spleen homogenato preserved at $-79^{\circ} \mathrm{C}$ for four months

Figs, 3 and 4. Touch preparations from liver of same animal Figs. 5 and 6. Smears from homogenate of $I_{\text {. }}$. donovani infected spleen showing parasites lying free in fluid and assuming spindle shape Smears were stained in Wrights-Giemsa, photographed under oil

liver of cach of these animals exhibited severe overwhelming infections (Figs. 1-4).

The viability and infectivity of Leishmania donovani obtained from homogenized organs were retained after storage for four months at $-79^{\circ} \mathrm{C}$ in Alsevar's solution. The survival in the frozen state of other intracellular parasites, especially those inhabiting the reticulo-endothelial system and the $L$. donovani stages of Trypanosoma cruzi under similar laboratory conditions, may also be possible.

\section{HarRy MOST} NELDA ALGER

Department of Preventive Medicine,

New York University School of Medicine, New York 16.

${ }^{1}$ Coggeshall, L. T., Proc. Soc. Exp. Biol. Med., 42, 499 (1939).

${ }^{2}$ Manwell, R. D., and Jeffery, G. M., Proc. Soc. Exp. Biol. Med., 50, 224 (1942).

${ }^{3}$ Jellery, G. M., and Rendtorfl, IR. C., Exp. Parasit., 4, 445 (1955).

‘ Jeffery, G. M., J. Parasit., 43, 488 (1957).

s Molinari, V., Trans. Roy. Soe. Trop. Med. Hyg., 54, 2, 288 (1960).

'Jeffery, G. M., J. Parasit., 48, 601 (1962).

"Polge, C., and Soltys, M. A., Trans. Roy. Soc. Trop. Med. Hyg., 51, 519 (1957).

\section{Antimicrobial Activity of Organogermanium Derivatives}

IN a recent paper ${ }^{1}$ comparative test results were presented regarding tho antifungal and antibacterial activities of a series of fourth main group organometallic acetates. It was reported that Mycobacterium phlei is highly sensitive to several trialkylgermanium acetates of the general structure $R_{3} \mathrm{GeOOCCH}_{3}$, wherein $R$ is butyl, isobutyl, pentyl or isopentyl. A concentration of $2-5$ $\mathrm{\mu g} / \mathrm{ml}$. caused complete suppression of visible growth.

As these results encouraged a continuation of the search for other sensitive organisms, the activity of a series of trialkylgermanium acetates towards a number of pathogenic and non-pathogenic fungi and bacteria has been investigated. Some of the more interesting result: are given in Table 1. A detailed report of this work will be published shortly ${ }^{2}$.

Table 1. Growth-INHIBITING ACTIVITY OF SOME TRIALKYLGERANIVM ACETATES (GENERAL STRUCTURE $R_{3} \mathrm{GEOOCCH}_{3}$ ) TOWARDS VARIOUS MICRO-

\begin{tabular}{|c|c|c|c|c|}
\hline \multirow{5}{*}{$\begin{array}{l}\text { Species } \\
\text { I Fungi } \\
\text { Glomerella cingulata } \\
\text { Trichophyton mentagro- } \\
\text { phytes } \\
\text { Cryptococcus neo- }\end{array}$} & \multicolumn{4}{|c|}{ Minimal inhibitory concentra- } \\
\hline & Medium & $\begin{array}{l}k= \\
\text { ethyl }\end{array}$ & $R=$ & $R=$ \\
\hline & & & 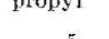 & \\
\hline & Peptone glucose agar & 10 & 5 & 10 \\
\hline & Blood ayar & 10 & 100 & 100 \\
\hline formans & Blood agar & 10 & 300 & $>300$ \\
\hline $\begin{array}{l}\text { Candida albicans } \\
\text { Debaryomyces }\end{array}$ & Blood agar & 100 & 300 & $>300$ \\
\hline nicotianae & Peptone glucose agar & 2 & 50 & $>.500$ \\
\hline $\begin{array}{l}\text { II. Gram-positive bac } \\
\text { Bacillus mycoides } \\
\text { Streptococcus lactis } \\
\text { Staphylococcus aureus * }\end{array}$ & $\begin{array}{l}\text { teria } \\
\text { Peptone glucose agar } \\
\text { Peptone glucose agar } \\
\text { Peptone glucose oxo }\end{array}$ & $\begin{array}{r}500 \\
50\end{array}$ & $\begin{array}{r}50 \\
5\end{array}$ & $\begin{array}{r}20 \\
1\end{array}$ \\
\hline Mycobacteriu & agar & $200-1,000$ & $50->104$ & $>500$ \\
\hline $\begin{array}{l}\text { tuberculosis* } \\
\text { Mycobacterium phlei }\end{array}$ & Egg yolk agar & $>100$ & $30 \sim>100$ & $>100$ \\
\hline (ref. 1) & Peptone glucose agar & 500 & 20 & 2 \\
\hline
\end{tabular}

* Several strains of this organism have been tested.

These results support the conclusions reached previously $^{1}$ that in the trialkylgermanium series triethylgermanium acetate is generally the agent most active towards fungi, including yeasts, whereas Gram-positive bacteria are inhibited more strongly by the propyl and butyl analogues.

The fact that in some cases considerable antimicrobial activity has been found among tho trialkylgermanium compounds may encourage the study of these compounds as potential chomotherapeutic agents. Proliminary results of toxicity studies carried out elsewhere have, moreover, given indications that oral toxicity of these compounds for mammalians is comparatively low.

This work was supported by the Germanium Research Committeo.

A. KaARs SiJpesteijn

F. RIJKENS

G. J. M. VAN DER KERK.

Institute for Organic Chemistry T.N.O., Utrecht, The Netherlands.

A. Manten

National Institute of Publie Health. Utrecht, The Nethorlands.

${ }^{1}$ Kaars Sijpesteijn, A., Rijkens, F., Luijten, J. G. A., and Willemsens, L. C., Antonie van Leeuwenhoek, 28,346 (1962).

${ }^{2}$ Kaars Sijpesteijn, A., Rijkens, F., Kerk, G. J. M. van der, and Manten, A. Antonie van Leeuwenhoek (in the press).

\section{GENETICS}

\section{Balanced Combinations of Polygenes}

SCHARLOO ${ }^{1}$ has discussed certain of our results ${ }^{2}$ in relation to what he purports is a summary of Mather's ideas concerning polygenic balance. We feel it necessary to criticize his communication inasmuch as it seems to us misleading in at least four ways.

(1) The first of these involves misrepresentation of Mather's views, for Scharloo's summary of these views includes the dogmatic statement "Polygenes have no pleiotropic action". Now Mather has been at pains to point out that linkage inter-connecting polygenic systems can have effects similar to those that pleiotropy could give rise to, and has provided clear evidonce that ploiotropy is not a sufficient explanation of his experimontal results. 